\title{
Pengaruh Kematangan Pribadi dengan Kecenderungan Cinderella Complex pada Wanita Dewasa Awal
}

\author{
Tasya Aulia Zahrawaany1, Siti Suminarti Fasikhah ${ }^{2}$ \\ Fakultas Psikologi, Universitas Muhammadiyah Malang \\ e-mail: ${ }^{1}$ shasya02@gmail.com
}

\begin{abstract}
A$ healthy person is a person who always develops in new states that require adjustment, while an unhealthy individual is when individuals do not use the potential that can be maintained and used in their lives, specifically for women who actually can increase their potential. The purpose of this study was to study the infuency of personal maturity towards Cinderella Complex in early adult women. This study used a correlational research design, using an accidental sampling technique with help of google form. The subjects were 2956 early adult women aged 18-25 years. The instrument in this study used a scale of personal maturity and the scale of the findings of the cinderella complex inventory. Data is analyzed using simple linear regression analysis. The results showed that there were effects of personal maturity towards complex Cinderella tendencies in early adult women. The value of regression coefficient is -0.390 with $p=0,000<0.05$. This result shows that the higher the personal maturit in earl adult woman, the lower cinderella complex tendency in individuals. The influence of personal maturity towards the tendency of Cinderella complex in early adult women is about $34.7 \%$. This research can be used as a material consideration to arrange psychoeducation program as a preventive effort.
\end{abstract}

KEYWORDS Self Maturity, Cinderella Complex, Early Adult Women.

CITATION Zahrawaany, T., \& Fasikhah, S. (2019). Pengaruh kematangan pribadi dengan kecenderungan cinderella complex pada wanita dewasa awal. Cognicia, 7, (1), 139-152.

Sosok perempuan cenderung dipandang sebagai pribadi yang penyayang, lemah-lembut, ingin dan harus dilindungi, dan penurut. Sedangkan laki-laki lebih dipandang sebagai pribadi yang memiliki kepemimpinan, pelindung, sosok kuat, dan lebih akrab dengan dunia kerja. Dalam Nurhayati (2012) didasari dari pendapat Whitning dan Edwards, perempuan adalah makhluk pasif dan lemah sebaliknya sosok laki-laki dipandang agresif dan aktif dalam masyarakat. Hal ini dikarenakan pengaruh budaya yang menyebabkan perempuan dididik dan dibesarkan dengan memberikan mereka secara tidak langsung bahwa mereka adalah makhluk lemah dan mereka pada akhirnya akan diberikan pilihan bahwa mereka akan memiliki sandaran hidup untuk tidak mandiri sehingga memunculkan perilaku ketergantungan. Ketakutan perempuan akan kemandirian di hidupnya ini disebut cinderella complex atau biasa dikenal cinderella syndrome yang ditemukan oleh Collete Dowling diawal tahun 1980-an. 
Istilah cinderella complex didapatkan dari dongeng Cinderella yang sudah terkenal di seluruh dunia. Dengan ceritanya mengenai wanita cantik yang baik hati tetapi menjadi korban kejahatan dari ibu dan saudara tirinya, yang akhirnya tokoh Cinderella dengan kebaikan hatinya, kepatuhan dan kemampuan mengurus rumah tangga membuat dirinya mendapatkan akhir bahagia dari pinangan seorang pangeran. Dalam cerita dongeng Cinderella terdapat hal-hal yang difokuskan, yaitu; pemeran utama yang cantik, baik hati, dan mengalami penurunan status atau derajad, kemudian setidaknya ada orangtua atau saudara yang memperlakukan semena-mena, lalu akan muncul kekuatan sihir yang membantu Cinderella sebagai pemeran utama sehingga pada akhir cerita harus menceritakan tentang bagaimana kembalinya status pemeran utama (Su \& Xue, 2010). Jika diumpamakan dalam kehidupan nyata, pangeran dalam cerita digambarkan sebagai penyelamat dan dengan menikahi.

Cinderella sang pemeran utama akan membebaskan Cinderella dari perlakuan semena-mena keluarga tirinya dengan begitu Cinderella kembali menduduki status yang bahkan lebih tinggi (Wang \& Liao, 2017). Cinderella complex dikemukakan oleh Collete Dowling seorang terapis di New York berdasarkan pengalamannya di tahun 1980 an, ia mengidentifikasi beberapa wanita saat itu di usia belasan memilih untuk menikah dibandingkan harus mengejar akademiknya. Dowling melakukan wawancara dengan beberapa wanita dari berbagai usia. Dari hasil yang didapatkan, kebanyakan kecenderungan cinderella complex dialami oleh perempuan mulai usia belasan tahun bahkan hal ini dialami pula oleh wanita yang telah menempuh pendidikan perguruan tinggi saat mereka mulai terjun pada masyarakat sesungguhnya. Sehingga kecenderungan ini dirasa memang sudah dimiliki oleh semua perempuan yang terpupuk mulai lahir hingga mereka dewasa. Hanya saja sebagian besar perempuan tidak menyadari bahwa mereka memiliki kecenderungan ini sehingga mereka tidak ada usaha untuk mengatasi hal tersebut (Dowling, 1992).

Jika dijelaskan mengenai kecenderungan ini bisa dikatakan bahwa Cinderella complex adalah kecenderungan perempuan merasa tergantung secara psikis yang telah terbentuk bahwa mereka memiliki keinginan untuk selalu diselamatkan, dilindungi, disayangi. Mereka percaya bahwa mereka adalah wanita yang sedang berada dalam kesulitan sehingga membutuhkan bantuan dan perlindungan dari laki-laki. Seperti kisah Cinderella dalam dongeng, bahwa perempuan menunggu seorang "pria" datang dan menolong untuk mengambil kendali hidupnya sehingga ia dapat hidup bahagia dengan berdiri dibelakang prianya. Kecenderungan cinderella complex ini menekan sikap mereka untuk mencapai kemampuan maksimal mereka dalam berpikir dan bertindak lebih hanya untuk menunggu seseorang atau sesuatu dari luar untuk mengubah hidupnya (Saha \& Safri, 2016). Tetapi disamping hal tersebut, tidak semua perempuan tidak mampu menghindari kecenderungan Cinderella complex, dalam Dowling (1992) disebutkan bahwa bagi perempuan yang memiliki keberanian untuk berdiri sendiri dan mau menghadapi risiko walaupun mereka menyadari keinginan terbesar mereka untuk merasa aman dan merasa dilindungi sehingga mereka mampu membangkitkan dirinya bersamaan dengan pengertian realistis tentang siapa mereka dan apa yang mampu mereka capai. Para perempuan ini disebut sebagai rapuh tetapi penuh keberanian (courageously vulnerable). Sehingga mereka mampu menghadapi hidupnya yang dalam keadaan tertekan dan bangkit untuk menghadapi dirinya 
sendiri sehingga pada akhirnya mereka mampu mengatasi ketakutan dalam dirinya yang membuat mereka terdiam dalam rumah yang membuat mereka tidak mampu mengembangkan dirinya.

Seperti yang disebutkan sebelumnya bahwa tidak semua perempuan mampu menghindari kecenderungan cinderella complex. Tetapi dalam beberapa penelitian menunjukkan beberapa range usia perempuan yang mengalami kecenderungan cinderella complex. Dalam penelitian Hapsari (2014) menjelaskan bahwa kecenderungan cinderella complex dialami oleh remaja perempuan. Data dari hasil penelitian sebelumnya menunjukkan sebagai berikut:

Tabel 1. Hasil Studi Pendahuluan Cinderella Complex

\begin{tabular}{ccccc}
\hline \multirow{2}{*}{ Cinderella complex } & \multicolumn{2}{c}{ Usia } & \multirow{2}{*}{ Jumlah } & \multirow{2}{*}{ Persentase } \\
\cline { 2 - 3 } & $\mathbf{1 6 - 1 8}$ thn & $\mathbf{1 8}$ thn ke atas & & \\
\hline Rendah & 34 orang & 23 orang & 57 orang & $63,33 \%$ \\
Tinggi & 26 orang & 7 orang & 33 orang & $36,67 \%$ \\
\hline
\end{tabular}

Data tabel diatas menunjukkan dalam penelitiannya dijelaskan mengenai hasil studi pendahuluan mengenai cinderella complex bahwa remaja usia 16-18 tahun lebih mengalami kecenderungan cinderella complex dibandingkan yang berusia 18 tahun ke atas. Jika dilihat apa yang dialami oleh perempuan dengan usia diatas 18 tahun dari beberapa penelitian sebelumnya adalah penelitian yang ditujukan untuk mahasiswi dengan rentang usia 19-21 tahun di salah satu universitas di Taiwan menjelaskan bahwa mereka dengan kecenderungan cinderella complex percaya bahwa dengan bertingkah laku feminin, penurut, lebih memikirkan hubungan personal, dan menjadi pengasuh anak-anak dan mampu mengurus urusan rumah tangga akan membantu mereka dalam menemukan pangeran mereka sehingga mereka sebagai perempuan mampu hidup tanpa mengkhawatirkan banyak hal (Wang, 2017). Sehingga karena mereka yang lebih mencari laki-laki untuk membenahi hidupnya, mereka cenderung menjadi pribadi yang tidak mampu membangun identitas dirinya karena mereka terlalu sibuk menyusun identitas laki-laki idamannya.

Pada wanita dengan usia 25 - 55 tahun pun memiliki kecenderungan ini. Penelitian yang menjelaskan kecenderungan cinderella complex pada wanita yang telah berkeluarga khususnya yang tidak bekerja memiliki kencenderungan ini. Wanita yang memiliki peran tunggal untuk menjadi ibu rumah tangga akan lebih banyak menghabiskan waktu di rumah dengan anak dan lingkungan sekitarnya hal ini dikarenakan segala sesuatu yang dibutuhkan telah dipenuhi oleh suaminya (Padma, 2007). Dalam penelitian ini disebutkan walaupun wanita sebagai ibu rumah tangga dan tidak bekerja lebih memiliki proporsi yang besar dalam kecenderungannya dalam cinderella complex, hal ini tidak menutup kemungkinan pada ibu rumah tangga yang bekerja juga memiliki hal tersebut karena mereka juga memiliki konflik emosional dalam dirinya mengenai peran gandanya sebagai ibu rumah tangga dan seorang pekerja, hanya saja bentuk perilaku yang mereka tunjukkan berbeda dan lebih rendah dibandingkan dengan ibu rumah tangga yang tidak bekerja.

Dari penjelasan sebelumnya dapat dilihat bahwa secara sadar atau tidak, fenomena cinderella complex ini dialami oleh semua wanita walaupun dengan taraf 
kecenderungan yang berbeda-beda. Pertolongan yang diterima terus menerus oleh perempuan sejak kecil sampai dewasa akan menimbulkan perasaan aman dan rasa nyaman pada perempuan ketika ia memiliki sosok yang mampu berdiri di depannya untuk menjadi tergantung pada orang lain (Dowling, 1992). Perempuan pada masa usia remaja lebih cenderung memilih untuk tidak mampu berdiri sendiri adalah karena kecemasan mereka dalam menghadapi masa depan yang tidak pasti dikarenakan dirinya yang merasa kurang dalam kemampuan dirinya akademik maupun non akademik. Sedangkan perempuan di usia dewasa yang memiliki kecenderungan Cinderella complex ini berbeda dengan yang dialami usia remaja bahwa mereka para perempuan usia dewasa yang sudah mengemban lebih banyak pengalaman, lebih banyak pengetahuan dan skill ini sehingga mereka turun dalam masyarakat untuk memberikan andil di dalamnya tetapi dengan mereka yang memiliki kecenderungan ini membuat mereka tidak memiliki keberanian untuk turun dan membiarkan dirinya bebas berkarya dan bermanfaat bagi masyarakat dan bagi dirinya sendiri.

Apalagi pada zaman sekarang yang dipandang serba modern dan serba instan memicu perilaku ketergantungan pada orang lain. Dan hal ini menjadi salah satu fenomena mengapa perempuan menjadi pribadi yang kurang berinisiatif dan kurang tegas dalam menjalani dan mengembangkan hidupnya. Dilihat dalam penelitian oleh Hays (2013) yang menjelaskan bahwa perempuan cenderung berada pada sisi keinginan untuk hedonisme dibandingkan laki-laki. Jika dilihat dari hal tersebut sisi hedonisme yang mendorong perempuan untuk mengikuti keinginannya, utamanya di zaman modern yang di dalamnya juga menuntut untuk mengikuti arus, sehingga perempuan cenderung memiliki keinginan untuk mengikuti gaya hidup zaman sekarang dengan cara yang cepat. Didukung pada penelitian Hays bahwa perempuan juga cenderung memiliki keinginan tinggi dalam aspek status dibandingkan kekuasaan (power). Sehingga rentan para perempuan yang hidup pada zaman serba modern dan instan ini karena secara tidak langsung mereka akan merasa dituntut untuk memenuhi kebutuhan dari dorongan-dorongan dalam diri mereka. Selain itu pada penelitian lainnya menunjukkan bahwa laki-laki memiliki keinginan kekuasaan (power), altruism, dan keinginan untuk berdagang (commerce) yang tinggi dibanding perempuan (Davies, Broekema, Nordling, \& Furnham, 2017) sehingga perempuan akan cenderung bersandar untuk mengandalkan hidupnya pada laki-laki. Hal ini sesuai dengan penjelasan bahwa memang para perempuan memiliki kecenderungan cinderella complex dalam dirinya.

Jika dilihat dari mana awal sikap ketergantungan tersebut muncul, sesuai dengan penelitian mengenai pola asuh berwawasan gender bahwa pengaruh lingkungan keluarga atau pola asuh orang tua berpengaruh besar pada perkembangan psikologis anak. Hasil penelitian menunjukkan bahwa pola asuh berwawasan gender memiliki pengaruh terhadap timbulnya kecenderungan cinderella complex. Pola asuh berwawasan gender yang dimaksudkan adalah bagaimana orang tua menunjukkan kesetaraan, keadilan dan tanggung jawab dalam pengambilan keputusan, pembagian tugas, bukan hanya antara orang tua-anak tetapi antara ayah-ibu-anak sehingga akan terbentuk kemandirian dan orientasi masa depan anak (Anggriany, 2003). Ketika anak sejak dini diberikan pemahaman mengenai laki-laki dan perempuan memiliki 
kesempatan dan penguasaan yang adil maka akan tumbuh kesadaran pribadi untuk bertanggung jawab pada dirinya sendiri sedangkan mereka yang tidak diberikan pengertian tersebut sejak dini akan menunjukkan perilaku sebaliknya (Anggriany, 2003). Sehingga dengan pola asuh berwawasan gender diterapkan mampu mengembangkan anak ketika mereka beranjak dewasa mampu bertanggung jawab dan mengontrol dirinya dalam kehidupan zaman yang semakin maju dan modern.

Sesuai dengan perkembangan zaman, peran perempuan kini cukup besar pada aspek kehidupan. Kini banyak perempuan di masyarakat yang berperan di dalamnya. Peningkatan peran ini terlihat dari berbagai macamnya perempuan menekuni pekerjaan saat ini. Pekerjaan kantoran, bekerja di pabrik, atau menjadi pedagang. Bahkan terdapat perempuan yang bekerja sebagai buruh atau tukang. Dalam bidang ilmu pengetahuan pun perempuan juga telah memiliki andil dalam berperan di dalamnya sebagai guru, peneliti, atau dokter. Penelitian yang dilakukan oleh Barsh \& Yee (2012) di Inggris menemukan bahwa terdapat 53\% perempuan sebagai pekerja sebagai pegawai dan sebesar $40 \%$ diantaranya berada sebagai level manajer. Sehingga dengan perempuan di masyarakat yang pastinya dihadapkan dengan tantangan untuk menghadapi bukan hanya kelompok perempuan lainnya tetapi juga para laki-laki sehingga muncul fenomena sulitnya mencari pekerjaan untuk bersaing dengan berbagai pihak. Akan muncul rasa harga diri yang rendah ketika para perempuan melihat teman mereka bekerja, sedangkan ia tidak mampu setara dengan hal tersebut. Perempuan sebagai pribadi yang sensitif dengan lingkungannya, bagaimana ia melihat lingkungannya dan sensitif mengenai bagaimana orang lain melihat dirinya hingga membuat harga dirinya turun. ketika hal tersebut terjadi akan muncul perasaan putus asa dan wanita akan mencapai pilihan untuk berkeluarga, memiliki suami mapan sehingga ia tidak perlu repot memikirkan masa depannya dan merasa cukup dengan sosok laki-laki yang mampu ia andalkan dalam hidupnya.

Fenomena-fenomena yang terjadi tersebut menggambarkan perilakuperilaku wanita yang mengarah pada kecenderungan Cinderella Complex. Menurut Dowling (1992) terdapat karakteristik yang ditunjukkan pada individu dengan Cinderella Complex : perempuan telah diedukasi bahwa mereka patuh dan inferior terhadap lakilaki, banyak perempuan menunjukkan sisi diri mereka yang besar mulut padahal sebenarnya mereka kekurangan kepercayaan diri dan tidak tau bagaimana menghadapi hidupnya, secara tidak sadar mereka menunggu "pangeran" mereka untuk menunggu dan menjaga dirinya, para perempuan ini cenderung mengidolakan ayahnya dan berusaha keras untuk mencari perhatian laki-laki, dan para perempuan ini berusaha menggambarkan dirinya untuk menggambarkan identitas laki-laki yang diinginkannya (Wang, 2017). Sehingga fenomena Cinderella Complex secara sadar atau tidak sadar dapat diketahui bahwa kecenderungan ini dialami oleh semua wanita, tetapi dengan taraf kecenderungan yang berbeda di setiap usianya. Hal ini menyebabkan alasan mengapa peneliti mengambil wanita pada masa dewasa awal adalah dengan alasan pada masa dewasa awal ini ketika seseorang memang harus menentukan rencana hidupnya dan masa dimana seseorang harus benar-benar terjun langsung pada masyarakat luas (Santrock, 2012).

Dari paparan yang dijabarkan, kecenderungan cinderella complex pada dalam diri wanita muncul karena beberapa faktor. Faktor dari luar seperti gaya hidup yang 
modern dan instan atau peran ganda perempuan yang kini semakin umum muncul sebagai pekerja dan pengasuh. Dalam penjelasan oleh Zain (2016) juga menyebutkan faktor yang mempengaruhi Cinderella Complex adalah pola asuh orang tua, konsep diri, dan kematangan pribadi. Didukung oleh Allport (dalam Alwisol, 2007) menjelaskan bahwa pribadi yang tidak matang tidak mampu memaksimalkan dan menyalurkan potensi yang dimilikinya, selain itu memiliki penerimaan diri atau harga diri yang rendah, selain itu ketidakmampuan menyesuaikan gambaran dirinya dengan keadaan sesungguhnya di masa sekarang. Hal-hal tersebut yang menunjukkan tanda bahwa individu tidak matang pribadinya.

Seperti yang dikatakan oleh Allport bahwa pribadi yang sehat adalah pribadi yang selalu berkembang walaupun berada pada kondisi yang berbeda, sedangkan pribadi yang tidak sehat adalah ketika individu perkembangannya berhenti dalam artian individu tidak menggunakan potensi dirinya untuk bertahan dan menjalankan kehidupannya. (Alwisol, 2007). Berdasarkan penjelasan tersebut, tujuan yang ingin dicapai oleh peneliti adalah untuk mengetahui pengaruh kematangan pribadi dengan kecenderungan Cinderella Complex pada wanita dewasa awal sehingga penelitian ini dapat memberikan manfaat selain memberikan gambaran pentingnya kematangan pribadi pada wanita dewasa awal sehingga para wanita tidak akan mengalami kecenderungan cinderella complex dan mampu memaksimalkan potensi dirinya, penelitian ini juga bermanfaat sebagai salah satu acuan untuk menyelenggarakan program psikoedukasi mengenai pentingnya pengembangan kematangan pribadi pada perempuan.

Dari beberapa penjelasan dari fenomena dan penelitian diatas mengenai kecenderungan cinderella complex masih belum ada yang menunjukkan seberapa besar kecenderungan cinderella complex yang lebih umum pada wanita. Sehingga beberapa penelitian hanya memfokuskan pada wanita yang menikah dan bekerja atau wanita menikah dan tidak bekerja atau hanya pada mahasiswi. Sedangkan dengan penelitian ini ditujukan untuk seluruh wanita dewasa awal sehingga hasil yang akan didapatkan akan lebih general melihat hubungan dari kecenderungan cinderella complex pada wanita dewasa awal.

\section{METODE}

Penelitian ini menggunakan pendekatan kuantitatif. Yaitu penelitian yang bertujuan untuk mendeskripsikan suatu fenomena atau keadaan tanpa adanya pemberian perilaku-perilaku tertentu terhadap objek penelitian dengan pengumpulan dan analisis data menggunakan ukuran, jumlah, atau frekuensi (Suryabrata,2009). Desain penelitian yang digunakan dalam penelitian ini adalah korelasional yang bertujuan untuk mengetahui ada atau tidaknya keterkaitan antar variabel (Frederick, 2014). Selain itu penelitian ini bertujuan untuk menjelaskan dan memprediksi kematangan pribadi dan kecenderungan cinderella complex.

Azwar (2003) berpendapat bahwa populasi adalah kelompok subjek yang hendak dikenai generalisasi dari hasil penelitian. Pada penelitian ini digunakan populasi wanita dewasa awal dengan usia 18-25 tahun. Setelah menentukan populasi yang hendak digeneralisasi, peneliti mengerucutkan menjadi sampel. Sugiyono (2017) mengungkapkan sampel adalah bagian dari jumlah dan karakteristik yang dimiliki 
oleh populasi yang sudah ditentukan. Pengambilan sampel dalam penelitian ini menggunakan accidental sampling yaitu pengambilan sampel anggota populasi yang dilakukan secara kebetulan, yaitu peneliti bertemu dengan calon responden yang sesuai sebagai sumber data melalui dunia maya atau internet dengan media penggunaan google form dalam penyebaran skala sehingga ketika terdapat responden yang sesuai maka mereka dapat mengisi skala tersebut. Sesuai dengan tabel Isaac \& Michael bahwa jumlah populasi subjek yang digunakan dalam penelitian ini tidak bias diketahui pasti sehingga penentuan sampel dalam penelitian untuk tingkat kesalahan sebesar 5\% digunakan minimal 350 subjek.

Pada penelitian ini terdapat dua variabel, yaitu variabel bebas $(X)$ dan variabel terikat $(\mathrm{Y})$. Untuk variabel bebas $(\mathrm{X})$ (independent variable) dalam penelitian ini adalah Kematangan pribadi dan variabel terikat (Y) (dependent variable) adalah kecenderungan Cinderella Complex.

Kematangan pribadi yang dimaksud dalam penelitian ini adalah individu yang menyadari kekuatan yang membimbing mereka dan dapat mengontrolnya. Individu yang terdorong oleh masa depan dan diarahkan masa sekarang dan memiliki intensi terhadap masa depan. Sehingga mereka sebagai individu yang bertanggung jawab akan dirinya sendiri, mampu beradaptasi dengan baik, mampu menerima kenyataan dan berpikir dewasa sehingga ia memiliki pandangan hidup ke depan dengan menyadari potensi dirinya sehingga mampu mengaktualikasiskan dirinya dengan memanfaatkan potensi dan bakatnya secara maksimal. Pengukuran variabel ini peneliti menggunakan skala kematangan pribadi yang berisi 30 item dengan keenam aspek yang sudah dipaparkan menurut Allport.

Cinderella Complex yang dimaksudkan disini adalah ketergantungan secara psikologis pada wanita dari rasa takut akan kemandirian yang menjadi sebuah tekanan dikarenakan keinginan yang tidak disadari pada wanita untuk dirawat dan dilindungi oleh orang lain yang membuat mereka berlindung dibalik orang lain dan tidak mampu memanfaatkan potensi yang mereka miliki walaupun sejatinya mereka memiliki potensi tetapi bersikap seakan-akan dirinya lemah dan membutuhkan perlindungan sehingga mereka memiliki ketakutan untuk mampu mandiri sehingga hal ini menekan sikap mereka untuk mencapai potensi dan bakat maksimal mereka dalam berpikir dan bertindak lebih hanya untuk menunggu seseorang atau sesuatu dari luar untuk mengubah hidupnya. Sehingga mereka cenderung selalu mengandalkan arahan orang lain, memiliki kontrol diri eksternal yang tinggi, harga dirinya rendah, menghindari tantangan dan kompetisi, mengandalkan laki-laki, dan ketakutan kehilangan feminitas. Kecenderungan Cinderella Complex ini diukur dengan skala Cinderella Complex berdasarkan teori Dowling yang dibuat berdasarkan keenam aspek tersebut dengan jumlah 20 item. Kedua alat ukur yang digunakan dalam penelitian ini menggunakan skala likert yang disusun dengan rentang 4 pilihan, yaitu: Sangat Sesuai (SS), Sesuai (S), Tidak Sesuai (TS), dan Sangat Tidak Sesuai (STS).

Tabel 2. Indeks Validitas dan Reliabilitas Alat Ukur Penelitian

\begin{tabular}{cccc}
\hline Alat Ukur & Jumlah Item Valid & Indeks Validitas & Indeks Reliabilitas \\
\hline Kematangan pribadi & 30 item & $0,308-0,646$ & 0,912 \\
Cinderella Complex & 20 item & $0,301-0,690$ & 0,908 \\
\hline
\end{tabular}


Penelitian yang akan dilakukan akan memiliki tiga prosedur penelitian, yaitu; 1.) Tahap persiapan, pada tahap ini peneliti melakukanpersiapan secara administratif maupun mempersiapkan alat ukur dengan penyebaran skala psikologi untuk uji coba atau try out dengan jumlah subjek try out minimal 30 orang dengan subjek wanita berusia 18-25 tahun. Selanjutnya peneliti akan melakukan analisa data menggunakan SPSS 21 (Statistical Package For Social Sciense) untuk mendapatkan item valid dan reliabel. 2.) Tahap Pelaksanaan, pada tahap ini setelah skala cinderella complex dan kematangan pribadi telah diuji sehingga didapatkan skala akhirnya kemudian peneliti menyebarkan skala tersebut pada wanita yang sesuai dengan karakteristik sampel yaitu wanita pada masa dewasa awal berusia $18-25$ pada sampel berjumlah minimal 350 orang. 3.) Tahap Akhir, pada tahap terakhir ini adalah tahap menganalisa hasil sebaran skala yang telah didapatkan dari lapangan. Skala berisikan item-item pengukur variabel cinderella complex dan kematangan pribadi dilakukan analisa pada kedua skala tersebut. Data akan diinput terlebih dahulu dan diolah menggunakan program SPSS 21, dengan analisis uji regresi linear sederhana.

\section{HASIL}

Subjek dalam penelitian ini adalah wanita dewasa awal dengan usia 18- 25 tahun dengan status menikah maupun belum menikah dan mereka yang bekerja dan yang tidak bekerja. Hal ini dapat dideskripsikan sebagai berikut:

Tabel 3. Deskripsi Subjek Penelitian

\begin{tabular}{lcc}
\hline \multicolumn{1}{c}{ Kategori } & Frekuensi & Presentase \\
\hline Usia & & \\
18 tahun & 358 & $12 \%$ \\
19 tahun & 426 & $14 \%$ \\
20 tahun & 473 & $16 \%$ \\
21 tahun & 548 & $19 \%$ \\
22 tahun & 495 & $17 \%$ \\
23 tahun & 284 & $10 \%$ \\
24 tahun & 213 & $7 \%$ \\
25 tahun & 159 & $5 \%$ \\
\hline Pekerjaan & & \\
Sedang bekerja & 659 & $22 \%$ \\
Tidak bekerja & 2297 & $78 \%$ \\
\hline Status & & $1 \%$ \\
Menikah & 44 & $99 \%$ \\
Belum menikah & 2912 & $100 \%$ \\
\hline Total & 2956 & \\
\hline
\end{tabular}

Dari tabel diatas dapat diketahui bahwa jumlah responden penelitian berjumlah 2956 orang. Diantaranya didominasi dengan wanita usia 21 tahun dengan jumlah 548 orang. Kemudian didominasi dengan wanita yang tidak bekerja sebesar 2297 orang dan sebesar 2912 orang yang berstatus belum menikah. Berdasarkan dari hasil 
penghitungan skor seluruh responden, dapat ditentukan dua kategori, yaitu sebagai berikut :

Tabel 4. Kategorisasi Kematangan Pribadi \& Kecenderungan Cinderella Complex

\begin{tabular}{ccccc}
\hline & Kategori & Interval & Frekuensi & Persentase \\
\hline \multirow{2}{*}{ Kematangan Pribadi } & Tinggi & Tscore $\geq 50$ & 1529 & $52 \%$ \\
& Rendah & Tscore $<50$ & 1427 & $48 \%$ \\
\hline Kecenderungan & Tinggi & Tscore $\geq 50$ & 1476 & $50 \%$ \\
Cinderella Complex & Rendah & Tscore $<50$ & 1480 & $50 \%$ \\
\hline
\end{tabular}

Dari tabel diatas dapat diketahui bahwa jumlah subjek yang memiliki kematangan pribadi tinggi sebesar 52\% (1529 orang), sedangkan jumlah subjek dengan tingkat kematangan pribadi rendah adalah sebesar 48\% (1427 orang). Dan untuk jumlah subjek dengan kecenderungan cinderella complex tinggi sebesar 50\% (1476 orang) selisih sedikit dengan jumlah subjek yang memiliki kecenderungan cinderella complex rendah sebesar 50\% (1480 orang). Hal ini menunjukkan bahwa terdapat lebih banyak subjek dengan kematangan pribadi yang tinggi dibandingkan dengan subjek dengan kematangan pribadi rendah.

Hasil dari uji linearitas antara variabel kematangan pribadi dengan kecenderungan cinderella complex didapatkan nilai signifikansi sebesar 0,072 dimana hal ini lebih besar daripada 0.05. maka dapat disimpulkan bahwa terdapat hubungan yang linier antara variabel kematangan pribadi dengan kecenderungan cinderella complex.

Tabel 5. Hasil Analisa Kematangan Pribadi \& Kecenderungan Cinderella complex

\begin{tabular}{ccccc}
\hline \multirow{2}{*}{ Kategori } & \multicolumn{4}{c}{ Kecenderungan Cinderella complex } \\
\cline { 2 - 5 } & $\boldsymbol{r}$ & $\boldsymbol{r 2}$ & $\boldsymbol{F}$ & $(\boldsymbol{p})$ Sig \\
\hline Kematangan Pribadi & 0,589 & 0,347 & 1572,247 & 0,000 \\
\hline
\end{tabular}

Analisis regresi linear sederhana yang dilakukan dengan menggunakan program SPSS 21 didapatkan hasil koefisien korelasi menunjukkan positif 0,589 dan signifikan. Hal ini menyatakan bahwa kematangan pribadi berpengaruh signifikan positif terhadap kecenderungan cinderella complex. Koefisiensi regresi sebesar -0,390 menyatakan bahwa setiap penambahan 1\% tingkat kematangan pribadi maka kecenderungan cinderella complex akan meningkat -0,390. Artinya bahwa semakin rendah kematangan pribadi seseorang maka akan tinggi kecenderungan cinderella complex dalam dirinya.

Pada analisis regresi, dasar pengambilan keputusan adalah ketika nilai signifikansi < 0,05 maka variabel bebas $(X)$ berpengaruh signifikan terhadap variabel terikat $(Y)$ sedangkan ketika nilai signifikansi $>0,05$ maka sebaliknya bahwa variabel bebas $(X)$ tidak memiliki pengaruh yang signifikan terhadap variabel terikat. Dari hasil yang telah didapatkan, nilai signifikansi adalah sebesar 0 dimana angka tersebut $<0,05$. Dari tabel di atas menunjukkan besarnya nilai F sebesar 1572,247 yang positif dan signifikan antara variabel kematangan pribadi dengan kecenderungan cinderella 
complex. Berdasarkan hasil uji regresi linier sederhana ini, besarnya koefisien determinasi ( $r$ square) adalah 0,347 , artinya ada pengaruh variabel $\mathrm{X}$ terhadap $\mathrm{Y}$ sebesar $34,7 \%$.

\section{DISKUSI}

Dari penelitian yang telah dilakukan, didapatkan hasil bahwa terdapat pengaruh signifikan antara kematangan pribadi dengan kecenderungan cinderella complex $(\mathrm{r}=$ $0,589 ; \mathrm{p}<0,05)$. Dengan nilai koefisien regresi sebesar -0,390, diketahui bahwa kematangan pribadi memilik pengaruh negative terhadap kecenderungan cinderella complex. Hasil penelitian ini membuktikan bahwa hipotesa yang menyatakan bahwa terdapat pengaruh negative kematangan pribadi terhadap kecenderungan cinderella complex ini dapat diterima. Pengaruh negatif ini menunjukkan bahwa semakin semakin rendah kematangan pribadi seseorang maka semakin tinggi kecenderungan Cinderella complex dalam dirinya. Sehingga ketika wanita memiliki kematangan pribadi yang rendah akan muncul perilaku-perilaku kecenderungan cinderella complex seperti selalu mengandalkan pihak luar bahkan tidak mampu dan tidak mau memaksimalkan potensi diri mereka untuk berkembang. Sehingga dengan terbuktinya hipotesa, ketika wanita mampu meningkatkan kematangan pribadinya maka dapat menurunkan perilaku-perilaku kecenderungan cinderella complex dalam dirinya.

Hasil penelitian ini sesuai dengan aspek dalam kecenderungan cinderella complex yang diungkapkan oleh Dowling (1992) menyebutkan bahwa terdapat aspek menghindari tantangan dan kompetensi. Wanita yang cenderung menghindari tantangan dan kompetensi dalam hidupnya akan sulit untuk berani mengambil inisiatif dan lebih memilih menghindari pekerjaan yang mereka rasa sulit dan beresiko. Sedangkan Allport menyebutkan bahwa individu semakin besar keterlibatannya dalam berbagai aktivitas yang tentunya memiliki relevansi dan memiliki arti pada individu itu sendiri, maka mereka dinilai semakin sehat dan matang pribadi individu tersebut. Hal tersebut diperkuat dengan penelitian oleh Davies, Broekema, Nordling, dan Furnham (2017) yang menunjukkan bahwa wanita lebih rendah dorongan atau keinginannya dalam mencapai kekuasaan dan keinginan untuk berdagang (commerce). Dari penelitian ini disebutkan bahwa wanita tidak besar dorongan dalam dirinya untuk melakukan sesuatu yang bisa mengeksplor dirinya maupun melakukan hal yang mampu memberikan benefit baginya.

Selain itu, penelitian yang dilakukan oleh Wulandari (2010) mengenai hubungan konsep diri dengan kecenderungan cinderella complex menunjukkan bahwa dari penelitiannya didapatkan hasil bahwa semakin positif konsep diri individu maka akan rendah tingkat kecenderungan cinderella complex. Begitu pula sebaliknya, jika konsep diri individu rendah, maka akan tinggi tingkat kecenderungan cinderella complex dalam dirinya. Penelitian ini memperkuat aspek dalam kecenderungan cinderella complex bahwa individu dengan kecenderungan cinderella complex memiliki harga diri yang rendah. Sehingga wanita dengan kecenderungan cinderella complex sulit memiliki penilaian positif terhadap dirinya sehingga ia kurang mampu menerima diri sendiri secara apa adanya. Sehingga hal tersebut juga akan mempengaruhi cara wanita berinteraksi dengan lingkungannya dan bagaimana sikapnya ketika mereka dihadapkan pada sebuah kesempatan untuk mengembangkan dirinya. Mereka akan 
menekan aspirasi dan inisiatif dalam dirinya dikarenakan adanya perasaan tidak aman dan rasa ketidakpastian terhadap kemampuan dan nilai diri mereka yang akhirnya akan berpengaruh pada kognitif mereka yang selalu pesimis dan menunjukkan perasaan cemas ketika dihadapkan pada hal-hal baru atau pada sebuah masalah.

Penelitian lain oleh Dewi, dkk (2004) mengenai sebuah studi komparasi konsep diri dengan latar belakang budaya dan jenis kelamin. Menjelaskan bahwa konsep diri antara laki-laki dan perempuan adalah berbeda. Penelitian tersebut menjelaskan bahwa pada wanita yang memiliki konsep diri yang rendah akan menilai dirinya tidak lebih bernilai dibandingkan orang lain, keyakinan tersebut berasal dari persepsi yang mereka miliki dan dipengaruhi oleh perlakuan masyarakat yang berbeda terhadap laki-laki dan perempuan. Ketika stereotipe dari masyarakat yang secara tidak sengaja terinternalisasi dan disosialisasikan tersebut menjadikan wanita memiliki konsep diri yang rendah. Sesuai dengan aspek kematangan pribadi yang disebutkan Allport hal ini selain memperkuat aspek kematangan pribadi mengenai perluasan perasaan diri, hal ini juga memperkuat dalam salah satu aspek kematangan keamanan emosional dan penerimaan diri. Bahwa wanita yang rendah dalam aspek ini cenderung menghindari aksi berlebihan pada masalah yang menyinggung dirinya dan mampu mentoleransi emosinya dengan menjadikan emosi dalam dirinya menjadi emosi yang mampu membangun dirinya dan akhirnnya juga mampu menerima emosi-emosi orang lain. dari penjelasan tersebut, dapat diartikan bahwa ketika wanita dengan konsep diri yang rendah sehingga muncul perilaku kecenderungan Cinderella complex ini menunjukkan pula bahwa mereka memiliki kematangan pribadi yang rendah, bahwa mereka tidak mampu mentoleransi emosinya dan emosi dari orang lain yang akhirnya malah membuat mereka menjadi tidak mampu membangun dirinya.

Pada penelitian oleh Zain (2016), disebutkan pula mengenai bagaimana kecenderungan cinderella complex dalam perspektif psikologi perkembangan sosial dan emosi. Dari penelitian tersebut dapat dilihat bahwa perkembangan wanita secara sosial dan emosional akan memiliki persona atau sebuah konstruk psikologis yang timbul karena kebutuhan mereka untuk menyesuaikan diri dan bagaimana cara mereka beradaptasi dengan lingkungan. Dimana ia akan menunjukkan perilaku yang sesuai dengan harapan lingkungannya sehingga ia dapat merasa diterima oleh sekitarnya. Hal ini terbentuk sejak dini, khususnya perempuan selama tahap perkembangannya tumbuh rasa inferior, berawal dari perbedaan perlakuan yang diterima anak perempuan dan anak laki-laki sehingga standar peran gender dalam masyarakat terbentuk dalam diri perempuan bahwa mereka diharapkan untuk feminim. Dari hal tersebut membuat wanita menjadi Berperilaku sebagai makhluk yang lemah, tidak bisa mandiri, dan memerlukan perlindungan. Didukung dengan penelitian oleh Anggriyani (2003) mengenai pengaruh pola asuh berwawasan jender terhadap munculnya kecenderungan cinderella complex. Dari penelitian ini disebutkan bahwa pola asuh yang tidak menunjukkan kesetaraan, keadilan, dan tanggung jawab yang sama antara anak perempuan dengan anak laki-laki dalam mengambil keputusan, pembagian tugas yang cenderung membuat anak perempuan menjadi kurang mandiri ini menjadikan anak perempuan sejak dini telah ditanamkan bahwa mereka kurang mampu bertanggung jawab pada dirinya sendiri. 
Dari penelitian ini menyatakan bahwa terdapat pengaruh sebesar $12,2 \%$ antara pekerjaan dengan kecenderungan cinderella complex dan terdapat pengaruh sebesar $6,4 \%$ antara status pernikahan dengan kecenderungan cinderella complex. Sehingga dapat dikatakan bahwa hasil dalam penelitian ini menjelaskan mengenai seberapa besar pengaruh status pernikahan dan pekerjaan terhadap kecenderungan cinderella complex. Dalam penelitian oleh Padma (2007) yang membahas mengenai perbedaan cinderella complex pada wanita menikah yang bekerja dengan wanita yang tidak bekerja. Dari penelitian tersebut dijelaskan bahwa ibu rumah tangga yang tidak bekerja memiliki proporsi lebih besar terhadap kecenderungan cinderella complex dibandingkan ibu rumah tangga yang bekerja. Tetapi dalam penelitiannya juga menyebutkan bahwa ibu rumah tangga yang bekerja juga memiliki konflik emosional dalam dirinya sehingga baik wanita yang menikah dan bekerja atau yang tidak bekerja pun sama-sama memiliki kecenderungan yang sama hanya saja ditunjukkan dengan bentuk yang berbeda. Dari penelitian tersebut yang menunjukkan bahwa ketika wanita lebih memilih untuk menikah dan tidak bekerja memiliki lebih besar peluang mengalami kecenderungan Cinderella complex. Jika hal ini dijelaskan secara emosional, dalam salah satu penelitian oleh Khairani dan Putri (2008) bahwa wanita menikah memiliki tingkat kematangan emosi yang lebih rendah dibandingkan lakilaki, sehingga wanita yang menikah lebih mengutamakan perasaan dibandingkan rasionalitas dan logika dalam dirinya sehingga mempengaruhi bagaimana mereka membuat keputusan, menghadapi dan cara memecahkan permasalahan yang ada. Dan jika dilihat dari konteks wanita yang bekerja pada salah satu penelitian oleh Brescoll (2016) menjelaskan bahwa ketika wanita merambah dalam kesuksesan untuk pekerjaannya, mereka terkadang lebih sulit mengontrol emosi mereka sehingga banyak menghambat pekerjaan mereka. Dari hasil paparan diatas, dapat dikatakan bahwa penelitian ini dapat memperkuat penelitian sebelumnya mengenai aspek dalam kecenderungan cinderella complex bahwa wanita dengan kecenderungan ini memang lebih mengandalkan laki-laki sehingga mereka cenderung memilih untuk menikah dan mendapatkan perlindungan dan mendapatkan kasih sayang dari lawan jenis.

Dengan subjek wanita dewasa awal yang digunakan dalam penelitian ini, menjadikan sebuah kelebihan dari penelitian ini sendiri. Karena wanita dewasa awal dirasa lebih urgent karena pada masa ini, wanita mengalami pencarian pola hidup dalam dirinya yang membuatnya menentukan tujuan untuk memenuhi kebutuhan hidupnya. Sedangkan dalam salah satu hasil analisis menunjukkan bahwa preferensi wanita untuk memilih pola hidupnya sebagai masa reproduksi, masa dimana menjalin hubungan dengan orang lain lebih diutamakan dibandingkan menjalani masa pengaturan dimana sebagai masa untuk mengeksplor diri dalam berkarir. Subjek dari penelitian sebelumnya mengenai cinderella complex menggunakan kelompok tertentu, seperti penelitian cinderella complex terhadap mahasiswi saja atau terhadap wanita yang telah menikah. Pada penelitian ini dengan menggunakan subjek yang lebih luas, sehingga dapat melihat bagaimana kecenderungan Cinderella complex keseluruhan secara lebih umum dengan jumlah subjek yang banyak dalam penelitian ini terbilang cukup banyak untuk mewakili populasi wanita usia dewasa awal. Tetapi dengan desain penelitian korelasional yang digunakan dalam penelitian ini hanya 
menghasilkan penjelasan mengenai kedua hubungan antar variabel sehingga masih tidak mampu menjelaskan sebab akibat antar kedua variabel tersebut.

\section{SIMPULAN DAN IMPLIKASI}

Berdasarkan hasil penelitian, diperoleh hasil bahwa hipotesa penelitian diterima. Dimana dapat diartikan bahwa terdapat pengaruh negatif yang signifikan antara kematangan pribadi dengan kecenderungan Cinderella complex pada wanita dewasa awal. Hal ini menunjukkan adanya pengaruh negatif antara kematangan pribadi terhadap perilaku ketakutan wanita untuk mampu mandiri dan mampu mengeksplor diri mereka, sehingga mereka akan cenderung menginginkan untuk selalu diselamatkan, dilindungi, dan dilimpahi kasih sayang oleh orang sekitarnya khususnya pasangannya. Dari penelitian ini didapatkan bahwa kematangan pribadi memiliki pengaruh terhadap kecenderungan cinderella complex sebesar 34,7\%.

Penjelasan dari hasil penelitian tersebut mengenai adanya pengaruh negatif yang signifikan antara kematangan pribadi terhadap cinderella complex pada wanita dewasa awal. Dengan memahami pengaruh variabel tersebut, penelitian ini dapat dijadikan bahan pertimbangan pada pihak-pihak luar untuk menyusun program seminar maupun psikoedukasi mengenai pentingnya kematangan pribadi yang memiliki pengaruh cukup signifikan terhadap kecenderungan cinderella complex. Bahwa pentingnya individu dengan pribadi yang matang untuk masa sekarang dan masa depan wanita, apa saja faktor yang menyebabkan hal tersebut, dan bagaimana cara untuk menghindari aatau mencegah kecenderungan cinderella complex pada wanita dewasa awal. Peneliti selanjutnya yang hendak meneliti mengenai Cinderella complex dapat memperluas ruang lingkup penelitian dengan variabel-variabel yang baru sehingga dapat memperluas penelitian mengenai kecenderungan cinderella complex. Misalnya seperti penelitian bagaimana kematangan emosi wanita mempengaruhi kecenderungan cinderella complex.

\section{REFERENSI}

Alwisol. (2009). Psikologi Kepribadian. Malang: UMMPress.

Anggriany, N., \& Astuti, Y. D. (2003). Hubungan Antara Pola Asuh Berwawasan Jender dengan Cinderella Complex. Psikologika No.16 Th.VII, 41-51.

Azwar, S. (2003). Metode Penelitian. Yogyakarta: Pustaka Pelajar.

Barsh, J., \& Yee, L. (2012). Unlocking the full potential of women at work. Mc.Kinsey and Company .

Brescoll, V. L. (2016). Leading with their hearts? How gender stereotypes of emotion. The Leadership Quarterly 27 , 415-428.

Davies, S., Broekema, H., Nordling, M., \& Furnham, A. (2017). Do Women Want to Lead? Gender Differences in Motivation and Values. Psychology Vol 08, 27-43.

Dewi, E.K., dkk. (2004). Studi Komparasi Konsep Diri Ditinjau dari Latar Belakang Budaya dan Jenis Kelamin pada Siswa Sekolah Menengah di Semaran dan Wonosobo. Jurnal Psikologi UNDIP No. 2, Vol I. 144-159

Dowling, C. (1995). Tantangan Wanita Modern : Ketakutan Wanita Akan Kemandirian. Jakarta: Erlangga.

Hapsari, A. D. (2014). Cinderella Complex pada Mahasiswi (Studi Deskriptif pada Mahasiswi di Universitas Negeri Semarang). Semarang: SKRIPSI . 
Hays, N. A. (2013). Fear and loving in social hierarchy: Sex differences in Preferences for power versus status. Journal of Experimental Social Psychology, 1130-1136.

Hurlock, E. B. (2002). Psikologi Perkembangan Suatu Pendekatan Sepanjang Rentang Kehidupan Edisi Kelima. Jakarta: Erlangga.

Kartono, K. (2005). Teori Kepribadian. Bandung: Mandar Maju.

Khairani, R., \& Putri, D. E. (2008). Kematangan emosi pada pria dan wanita yang menikah muda. Jurnal Psikologi Vol.1, No.2, 136-139.

Nurhayati, E. (2012). Psikologi Perempuan dalam Berbagai Perspektif. Yogyakarta: Pustaka Pelajar.

Padma, A. (2007). Perbedaan Cinderella Complex pada Wanita Menikah yang Bekerja dan yang Tidak Bekerja. Yogyakarta: SKRIPSI.

Santrock, J. W. (2012). Life-Span Development Perkembangan Masa Hidup Edisi ketigabelas Jilid 2. Jakarta: Penerbit Erlangga.

Schultz, D. (1991). Psikologi Pertumbuhan : Model-Model Kepribadian Sehat diterjemahkan oleh Yustinus. Yogyakarta: Kanisius.

Sneha Saha, T. S. (2016). Cinderella Complex: Theoretical Roots to Psychological Dependency Syndrome in Women. The International Journal of Indian Psychology Volume 3, Issue 3, No. 8.

$\mathrm{Su}, \mathrm{T} ., \quad \&$ Xue, Q. (2010). The Analysisn of Transition in Woman Social Status--Comparing Cinderella with Ugly Betty. Journal of Language Teaching and Research Vol. 01, No.05, 746-752.

Sugiyono. (2017). Metode Penelitian Kuantitatif, Kualitatif, dan RED. Bandung: Alfabeta.

Sumpani, D. (2008). Kepuasan Pernikahan Ditinjau Dari Kematangan Pribadi Dan Kualitas Komunikasi. Surakarta: Skripsi thesis.

Suryabrata, S. (2009). Metodologi Penelitian. Jakarta: Raja Grafindo Persada.

Wang, Y.-h., \& Liao, H.-C. (2017). The Psychological Dependency Syndrome in Women of Taiwan--An Exploration of CInderella Complex. social.esmu.edu.tw, 27-38.

Wulansari, S. (2010). Hubungan antara Konsep Diri dengan Kecenderungan Cinderella Complex. Semarang: SKRIPSI.

Zain, T. S. (2016). Cinderella Complex dalam Perspektif Psikologi Perkembangan Sosial Emosi. Jurnal Indigenous Vol. 01 No. 01, 92-98. 